Abstracta Iranica

Revue bibliographique pour le domaine irano-aryen

Volume 34-35-36 | 2017

Comptes rendus des publications de 2011-2013

\title{
Gaby Abousamra, André Lemaire. Astarte in Tyre According to New Iron Age Funerary Stelae
}

\section{Astrid Nunn}

\section{OpenEdition}

1 Journals

\section{Édition électronique}

URL : http://journals.openedition.org/abstractairanica/41207

DOI : 10.4000/abstractairanica.41207

ISSN : 1961-960X

Éditeur :

CNRS (UMR 7528 Mondes iraniens et indiens), Éditions de l'IFRI

\section{Référence électronique}

Astrid Nunn, «Gaby Abousamra, André Lemaire. Astarte in Tyre According to New Iron Age Funerary Stelae », Abstracta Iranica [En ligne], Volume 34-35-36 | 2017, document 93, mis en ligne le 15 juillet 2016, consulté le 28 septembre 2020. URL : http://journals.openedition.org/abstractairanica/41207 ; DOI : https://doi.org/10.4000/abstractairanica.41207

Ce document a été généré automatiquement le 28 septembre 2020.

Tous droits réservés 


\title{
Gaby Abousamra, André Lemaire. Astarte in Tyre According to New Iron Age Funerary Stelae
}

\author{
Astrid Nunn
}

\section{RÉFÉRENCE}

Gaby Abousamra, André Lemaire. « Astarte in Tyre According to New Iron Age Funerary Stelae ». Die Welt des Orients, 43/2, 2013, p. 153-157.

1 De nombreux documents grecs et latins ainsi que quelques sources assyriennes attestent le lien entre Astarté et la ville de Tyr. Mais aucun document ne provenait de Tyr même avant la découverte fortuite de la nécropole à el-Bass. Trois des 34 stèles funéraires portent le nom d'Astarté. S'y ajoutent d'autres objets de collections privées où Astarté, déesse vénérée par les petites gens, apparait dans divers formulaires.

\section{AUTEURS}

\section{ASTRID NUNN}

Université de Munich 